\title{
DESACRALISING SHAKESPEARE'S “WORD” BY MEANS OF CULTURAL TRANSLATION/TRANSPOSITION
}

\author{
José Roberto O'Shea* \\ Universidade Federal de Santa Catarina
}

\begin{abstract}
This essay addresses ways in which cultural translation/ transposition can ultimately bring about a positive "desacralisation" of Shakespeare's Word. The discussion starts from the notion of Shakespeare's Word as "sacred" and of sacred writings as highly sensitive language, and proceeds to overview the importance of the notions of denotation, connotation, and context in translation. Then, the essay offers working definitions of cultural translation or cultural transposition, and of non-literal translation. Finally, the essay highlights the author's main aims in translating Shakespeare's theatre and offers a few examples of cultural translation/transposition in his own rendering of Shakespeare's drama into Brazilian Portuguese.
\end{abstract}

Keywords: Shakespeare. Theatre. Cultural translation/transposition. Brazilian Portuguese.

\section{DESSACRALIZANDO O "VERBO" SHAKESPEARIANO POR MEIO DE TRADUÇÃO/TRANSPOSIÇÃO CULTURAL}

Resumo: Este ensaio aborda procedimentos por meio dos quais a tradução/transposição cultural pode, em última instância, elicitar uma benéfica "dessacralização" do Verbo shakespeariano. A discussão parte da noção

\footnotetext{
* José Roberto Basto O'Shea: PhD (1989) in English (Literature) from the North Carolina System at Chapel Hill, USA. MA (1981) in Literature from the American University, USA. BA in Business Administration by the University of Texas at El Paso, USA. Professor of English and American Literature at the Federal University of Santa Catarina (UFSC). Florianópolis, Santa Catarina, Brasil. E-mail: oshea@cce.ufsc.br
} 
do Verbo shakespeariano enquanto algo "sagrado" e de escritos sagrados enquanto linguagem sumamente sensível, e prossegue, apresentando uma visão geral das noções de denotação, conotação e contexto, sob a perspectiva da tradução. Em seguida, o ensaio oferece definições operacionais de tradução/transposição cultural, bem como de tradução não-literal. Finalmente, o ensaio ressalta os objetivos do autor, ao traduzir o teatro shakespeariano, e arrola alguns exemplos de tradução/transposição cultural retirados de sua própria tradução do drama shakespeariano para a língua portuguesa na variante brasileira.

Palavras-chave: Shakespeare; Teatro; Tradução/transposição Cultural; Português Brasileiro.

Deliberately avoiding linguistic micro analysis, I would like to address ways in which translation can bring about what I am calling the "desacralisation" of Shakespeare's Word. That Shakespeare's words have been considered all but sacred is a truism. Back in 1966, Martin Lings's book Shakespeare in the Light of Sacred Art, drawing on Lings's own expertise in comparative religion, went so far as to propose mystical and spiritual meanings for the plays. Later, of course, Shakespeare's work gets to be seen as the fixed centre of the Western canon (or the canon itself), a "sacred text", a "secular Scripture" that has supposedly replaced the Bible in our secularised consciousness. Notoriously, for Harold Bloom, Shakespeare is "the only possible rival to the Bible", providing "an alternative vision . . . to the accounts of human nature and destiny in the Hebrew Bible, the New Testament, and the Koran" (How to Read 201). Still according to Bloom, Shakespeare's "rhetorical and imaginative resources" are seen as "transcend[ing] those of Yahweh, Jesus, and Allah", and "Hamlet's consciousness, and his language for extending that consciousness, is wider and more agile than divinity has manifested, as yet" (ibid).

It so happens that in sacred writings the words themselves are taken to be holy, hence "highly sensitive". Addressing the issue of textual sacredness, Karl Simms writes: 
What makes a text sacred is the belief that it expresses intentions of the Original Author, so that the 'author of the text' [or, for my purpose, the translator] [...] is merely a scribe, one who transcribes a[n] originary Word with which he is inspired. [...] It is a further characteristic of sacred texts that they declare their own sacredness internally, and in so doing themselves address questions of language and translation. (19, emphasis added)

In studying the nature of sacred, sensitive texts, it pays, initially, to return to notions of denotation and connotation, and not to neglect contextual concerns. A distinction between denotation and connotation has, of course, long been recognised by linguists, and need not be expanded on here. Suffice it to say that, as experienced by humans, communication depends far more on connotation than on denotation of words, that is, more on the context in which language is situated than on the referential function of language per se; "and it is precisely in this respect that language . . . is sensitive"-states Simms (2). To complicate matters, we should not be led to accept "a neat division between the denotative and the connotative, [nor] that pure denotation might be a refuge from the otherwise sensitive nature of language" (ibid.). As a matter of fact, "there is no 'pure' denotation in language. At every juncture denotation is infected by connotation, at least if we conceive of connotation as context" (ibid. emphasis added).

But how exactly is a sacred text sensitive? Taking into account the implications of connotation and context, Simms proposes that the sensitivity observed in sacred texts may be of three kinds: either the references made in the text are taboo, or the very existence of the text as such may be taboo-or both. Traditionally, texts may be considered sensitive on four grounds: contrary to state, to decency, to private citizens, or to religion (culture) (5). ${ }^{1}$ Ultimately,

${ }^{1}$ The four traditional grounds lead to another foursome of grounds for censorship: sedition, obscenity, libel, and blasphemy (Simms 5). 
textual sensitivity is a cultural issue, as sensitivity is governed by contingencies and, therefore, the perception of a text as "sensitive" changes according to History and Geopolitics, that is to say, context.

To be sure, the importance of context in theatre cannot be over stressed, since theatre texts are more often than not put together for a particular context, the "here and now" (Aaltonen 3). And since theatre in translation has an inescapable intercultural dimensionwhich, as Patrice Pavis has shown, places theatre both diachronically and synchronically at the "crossroads of culture" (5-10) - the specific context of a text's reception, in the last analysis, defines relevance and meaning. Indeed, especially in translation, meaning is constructed at the "crossroads of culture", at sites where "different systemic [. . .] idiolects or discourses compete for power" (Aaltonen 29).

But what are the connections among sacred and sensitive texts, cultural translation, and textual desacralisation? Referring to Bible translation, for instance, Eugene Nida asserts:

\begin{abstract}
Producing a translation of any text with a long and sensitive tradition creates a feeling of having some 2000 years of translators looking over one's shoulder. The problems of a long tradition are especially relevant in the case of religious texts, because there are always many people whose faith is based as much on the wording [itself] [. . . ] as on their content. (189)
\end{abstract}

In translating sensitive texts (religious or secular), translators have too often valued denotation and too often fallen into the trap of the so-called "faithful", "literal" translation. One of the main claims for literal translation is the mistaken idea that the meaning of a text depends on the "precise" rendering of the words as isolated units rather than in combinations. ${ }^{2}$

${ }^{2}$ Strictly speaking, "literal" translation is a misnomer, as there is no such thing as a purely literal translation, all translation involving varying degrees of paraphrase. 
And it is here that cultural translation, or cultural transposition, can become handy, defined by Sándor Hervey \& Ian Higgins as "the various degrees of departure from literal translation that one may resort to in the process of transferring the contents of a ST into the context of the target culture" (28). Going against literalness, an experienced theatre practitioner such as Peter Hall has observed that "precision [. . .] [is] not really a question of literal meaning. Anyone can come up with that, it's the subtext, it's what is underneath the text that you need to be led to" (387). All in all, it is the combination of words that carries (or constructs) meaning, "the conceptual level of communication [involving] not individual words, but words in context" (Nida 194-95).

The difficulty, however, is that too often the "literal" translator holds the source text sacrosanct, conceives the translation as an inferior extension of the source text, and attempts to be as "faithful" as possible, by rendering individual words of the source text into an illusive "equivalent" drawn from available, isolated dictionary attestations of the target language. The literal translator believes to be on the side of the author. Rejecting "domestication", the literal translation is made visible, "foreignised", since the target text is as near as possible a direct rendering of the original. ${ }^{3}$

Conversely, the "non-literal" translator foregrounds connotation, intervention, cultural translation, at times, indeed, "domestication". Conceptually, "a [non-literal] translation is a mirror image [. . .] of a literal translation" (Simms 7). ${ }^{4}$ Depending on the characteristics

3 I am referring to notions of "foreignising" and "domesticating", translation strategies expounded by Lawrence Venuti in The Translators Invisibility (1995). While Venuti criticises domestication strategies in the USA, since, in his view, domestication serves the hegemonic agenda of "aggressively monolingual cultures", I want to suggest that such strategy, in cultural contexts other than the Anglo-American, can be desirable, in this sense, reversing the political implications denounced by Venuti.

${ }^{4}$ I prefer the term 'non-literal' translation to 'free translation', since the latter may imply an exaggerated distance from the original text. Moreover, the categorisation of theatre texts into 'free' and 'faithful' translation of their source texts has been rejected as irrelevant (Aaltonen 53). 
of this "looking glass", and "on the strategies that have been used in the process of translation, [. . .] the [translated] culture will be more or less accessible [. . .] more or less visible" (Carbonell 94). Mistakenly, for the literally minded, the "non-literal" translation betrays the original author's "intentions". 5 Yet, to seek fidelity to a foreign author's "intentions" is to ignore the distance the originary text has travelled and, therefore, to become, unfaithful to the target culture. No doubt, avoiding "translationese", a non-literal translation places itself more on the side of the reader than of the author. Moving away from literalness and denotation, contemplating context and reception, the non-literal translation aims at connotative and cultural signification, and, when successful, can be highly faithful in terms of reproducing the artistic power of the original.

In its extreme form, non-literal translation becomes "cultural translation", the translation of lexical and cultural items into contemporary cultural equivalents, rather than into "equivalent" linguistic meanings. ${ }^{6}$ The procedure is based on the understanding that translation is ultimately realised with the purpose of integrating a foreign text into the aesthetics of the receiving culture as well as into the social discourse of the target society (Aaltonen 53). For traditionalists, cultural translation ought to be dismissed, both because of its "implied lack of respect for the original text, and because of the defeatist view of the abilities of the target audience which it entails" (Simms 10). For Peter Hall, however, theatre translation has to try to capture cultural difference, "to recognise it and try and find some equivalent" (389). For the less literally minded, therefore, cultural translation can be seen, in fact, "as a superior level of interaction [which] takes place whenever an alien

5 As regards the futile pursuit of an author's intentionality, Peter Hall has complained about translators who are so "slavishly pedantic" in presuming to express what "they think the author originally meant that they give something that is stilted and dead" (389).

${ }^{6}$ As an example of "cultural translation" of sensitive texts, Simms cites the phrase "sixty stadia" (Luke 24.13) becoming "about eleven kilometres" in the Good News Bible (8). 
experience is internalized and rewritten in the culture where that experience is received" (Carbonell 81).

Having translated a few of Shakespeare's plays, I value what John Barton has expressed as a balance between the "rigorous and [the] imaginatively free" (402), a soft spot between the challenges of historical accuracy, cultural otherness and contemporary domestication, that is, a translation which preserves a certain degree of literalness while assisting the reader where understanding might fail. Such assistance can be effected intratextually (by way of domestication strategies) or extratextually (by way of explanatory notes, for instance), both intra and extratextual procedures working as framing information for the target-text reader. In other words, under this perspective, the translator's work entails a complex hermeneutics: an interpretation that attempts to make sense of the foreign, devising procedures to render the foreign relatively familiar, while striving not to annihilate foreignness.

As regards diction, for instance, in the case of non-contemporary texts, one of the positive uses which a translator can make of domestication is lexical modernisation. ${ }^{7}$ However, in the case of sensitive texts, this is easier said than done. Interestingly, Nida points out that "The pressures on Bible translators to retain traditional forms of language are intense, [as] some people insist on a Bible that sounds old-fashioned, and even ancient, because that suggests that the text is closer in meaning to the original" (193-94). And, surely, many readers are intrigued, mystified by abstruse, archaic language. ${ }^{8}$

No doubt, all I've been saying about sensitive texts applies to Shakespeare's works, as many see such texts not only as a "secular

\footnotetext{
7 Jean-Michel Déprats has advocated 'rejuvenation' in an article in Shakespeare Survey 50 (see Bibliography below).

${ }^{8}$ I have addressed the complex issue of lexical updating elsewhere (see bibliography below). In any event, lexical updating is not to be confused with simplification, just as 'speakability', having more to do with the use of rhythm, cadence, is not to be reduced to verbal simplicity.
} 
Scripture", we recall, but also as a repository of cultural values. Desacralising Shakespeare's Word, a number of examples can illustrate modes of cultural translation-not only by way of verbal but also aural and visual language. Verbally, for instance, in her Brazilian rendering of Julius Caesar (1991), Margarida Rauen translated Erebus as hell and Ate as goddess of mischief.

In my own Os Dois Primos Nobres (2014), act 2, scene 3, the Primeiro Camponês says: "I am sure to have my wife as jealous as a turkey”. A literal translation, e.g., "Tenho certeza que minha esposa vai ficar ciumenta como uma perua", would be ludricous for the Brazilian reader/play-goer, as the word perua means, in back translation, "woman who affects elegance but who actually dresses too loud" (Dicionário Eletrônico Houaiss da Língua Portugesa). In this case, perhaps the option for another bird, pavoa (surely, in the feminine) seems to overcome the cultural impasse.

In the same play, same act, same scene, the Segundo Camponês says: "He's excellent in the woods; bring him to the plains, his learning makes no cry". A literal translation- "No bosque ele é excelente; levai-o pra campinas, e seu saber se cala"-seems inadequate, as it ignores the fact that for a Brazilian reader/playgoer Campinas is the name of an important city in the state of São Paulo. Alternatively, "para o campo aberto" (to the open field) both preserves the sense of the original speech and avoids the cultural trap.

In Tróilo e Créssida (2015), act 1, scene 2, we have:

\section{PÂNDARO}

Bem, sobrinha, ontem eu te contei uma coisa... pensa no que eu falei.

\section{CRÉSSIDA}

\section{PÂNDARO}

Estou pensando.

Juro que é verdade: ele vai chorar por tua causa como se fosse um homem nascido em março. 
In Shakespeare's play, the month is April, in the British tradition, the rainiest month. Minding the target culture, the translation has opted for March, in Brazil, the month "of the waters" celebrated in Tom Jobim's classic song "Águas de Março”.

Still in Tróilo e Créssida, now act 4, cena 2, we have:

\section{CRÉSSIDA}

Não irei, tio: meu pai já esqueci;

Para mim não há laços, parentesco, Amor, alma ou sangue mais chegados

Do que o doce Tróilo. Ó bons deuses!

[Make Cressid's name the very crown of falsehood]

Tornai o nome Créssida o diadema

Da falsidade, se ela deixar Tróilo.

The translation has privileged diadema, as opposed to the literal coroa because, for the Brazilian reader/play-goer, the latter also means, again in back translation: "individual nearing old age" (Dicionário Eletrônico Houaiss da Língua Portugesa).

And once again in Tróilo e Créssida, now act 5, scene 2, we have:

\section{ULISSES} TRÓILO

Fiquemos onde a tocha não nos mostre. [Entra Créssida]

Vem Créssida encontrá-lo.

\section{DIOMEDES}

Então, como estais, minha prisioneira?

\section{CRÉSSIDA}

Ah, meu meigo guardião, uma palavrinha. [Sussurra algo a Diomedes] TRÓILO

Tão íntimos? 


\section{ULISSES}

[She will sing any man at first sight.]

Ela é capaz de encantar qualquer homem

Logo à primeira vista.

\section{TERSITES}

[And any man may sing her, if he can take her clef.] sua clave.

E qualquer homem pode cantá-la, desde que se aposse de

In Ulisses's speech, sing gets translated non-literally as encantarwhich actually means to fascinate, to enchant-because for a Brazilian audience cantar also means "trying to seduce someone by means of gestures or words" (Dicionário Eletrônico Houaiss da Lingua Portugesa), a meaning that would at best be subtextual here. In Tersites speech, however, the verb gets translated literally, embracing the double entendre, as the double meaning "praise/ seduce" seems eloquently present.

Visually and aurally, Grigori Kosintsev's King Lear, read through Dostoevsky, thematising the agony over the meaningfulness of life and death, and referring to images of the destruction of Stalingrad (1971); Giorgio Strehler's approach to King Lear (1972), via the director's own cultural and historical context-i.e., images of Dante's Divina Commedia and of the liberation of Italy from Fascist rule (Bassnett 93-94); Gabriel Villela's Romeu e Julieta (1992) and A Tempestade (2015), incorporating Brazilian street theatre aesthetics, as well as, respectively, modinhas from Minas Gerais and candomblé from Bahia.

But the resumed approximation between Shakespeare and the Scriptures brings me back to Bloom and Hamlet. Bloom reiterates arguments previously advanced in The Western Canon (1994), in How to Read and Why (2000), in Shakespeare: The Invention of the Human (1998), and Hamlet: Poem Unlimited (2003): "bardolatry", the mythical worship of Shakespeare, ought to be even more a secular religion than it already is. Hamlet, the most 
cited figure in Western consciousness after Jesus, is the only secular rival to his great precursors (as we have seen, Yahweh, Jesus, and Allah). And the mythicization of Shakespeare and his sacred texts have had important implications not only for theatre practice and the study of Shakespeare's poetry but also for the translation of his work. Certainly, the "burden" of the myth can be so cumbersome as to make it sometimes difficult for the English-language theatre director to move (Bassnett 88). ${ }^{9}$ Moreover, in the case of the dramatic poetry, the fact that the playtexts have been set down based on something as unstable as performance rather than on any fixed writing has been too readily dismissed by some scholars.

Part of the difficulty is that, for people who have no awareness of the text's evolution, Shakespeare's plays have been perceived as absolutes. Now, if the playtexts are perceived as absolutes, their translation tends to be directed by normative, prescriptive attitudes, as opposed to more daring, creative stances. No doubt, Shakespeare's poetry is one of the major achievements of human art, but seen as cultural absolutes, the texts are considered sacred and may command too "high [a] regard for the "original" ", an agency which Sirkku Aaltonen has defined and criticised as "reverence" $(8,64-65){ }^{10}$ Yes, the difficulties in translating Shakespeare's playtexts are indeed many and formidable. ${ }^{11}$ However, to perceive

${ }^{9}$ Susan Bassnett retells the apocryphal tale of an East European director who, on leaving a British production of Shakespeare, remarked: "That's wonderful. Everything remains to be done. All they played was the text" (88).

${ }^{10}$ For Aaltonen reverence "characterises the choice of both the text and translation strategy when the 'Foreign' represents desirable cultural goods". And she adds that in the agency of reverence "the hope is that the translation will carry over some of the qualities of the source text and the culture it represents into the target system (8).

11 Delabastita offers the catalogue of such difficulties: textual cruces, obscure allusions, archaisms and neologisms, Anglo-Saxon and Latinate diction, images, metaphors, repetitions, personifications, puns, ambiguities, malapropisms, forms of address, elliptical grammar, flexible prosody, theatrical signs etc. (18). 
the text as absolute and sacred can cause unnecessary reverence and hinder, if not paralyse, a translator.

By contrast, a translator who is not overly reverential, not awed by the "sacredness" of Shakespeare's Word, and who realises that in translation one is in fact "displacing the author whilst at the same time wanting to clarify what the author has attempted to do" (Barton 407), may try to take advantage of linguistic and cultural displacement. And to understand the implications of displacing Shakespeare's sacred and sensitive original Word(s) by means of translation, it is helpful to remember the ways in which Shakespeare has operated on the stage and in the mind outside English-speaking contexts. Why do so? Because, as is known, Shakespeare is the most performed playwright over the globe, and because, despite the claims of universality which many insist on advancing, he is not in Japan, Finland or Brazil the same dramatist who is played at the Royal Shakespeare Theatre, in Stratford-upon-Avon, or at the Barbican, in London. In fact, despite globalisation, as Aaltonen asserts, "social and cultural changes have made it more and more difficult for people to read the world in even remotely similar ways" (6). The cultural connotations derived from playing Shakespeare in Britain and in English are simply not always applicable in another country and another language/culture.

In the collaborative experience of the theatre, readers, translators, directors, actors, designers and technicians construct their own readings, which proceed to be realised (directed) in a staging, and which will serve as the basis for the audience's construction of meaning (Aaltonen 6), unavoidably as a function of context. ${ }^{12}$ Hence, granting that Shakespeare's playtexts do not have fixed readings to be discovered and repeated in their translations, the construction of meaning which such works elicit is extremely complex. Moreover, as Dennis Kennedy argues, in a seminal article inspiringly titled "Shakespeare Without His Language", if the cultural attitudes

12 Aaltonen reminds us that the reading of a play varies from age to age, from culture to culture, from reader to reader, from performance to performance (37).

Cad. Trad., Florianópolis, v. 36, n⿳ 3, p. 124-139, set.-dez./2016 
inherent in the plays are to gain a sense of relevance, they "require not only linguistic translation but also cultural adaptation when [. . .] transferred to a foreign environment" (134). In a word, as Kennedy demonstrates, outside English-speaking environments, "the absence of linguistic and cultural connections to Shakespeare has meant that [. . .] appropriation has been more overt, and has met less official resistance from advocates of high culture than in the home countries" (135).

Although many native English-speakers may assume that foreignlanguage productions of Shakespeare lose "essence" 13 in the process of cultural and linguistic transfer, the fact is that some foreign productions may yield in translation a more direct access to the power of the plays, e.g., by means of domesticated, i.e., understandable, cultural referents, by means of emphasis on visual rather than verbal language, or by lexical updating - all of which can vouchsafe a sense of relevance and often redefine the meanings of the plays.

The view that translation is a mere replication of the source text is, therefore, crassly reductive. In fact, translation implies a concrete linguistic and cultural dislocation, transformation of the original; after all, the original text disappears in the new language. In translation, presented "without his language", Shakespeare's "sacred" Word is concretely displaced, linguistically and culturally. A few positive conclusions can be drawn from all of this: (1) that non-Anglophone Shakespeare challenges the idea that Shakespeare "can be contained by a single tradition or by a single culture or by a single language" (Kennedy 146); (2) that, in general, foreign productions of Shakespeare, "freed from the burden imposed by centuries of admiring his language" (ibid.), have been more ready to revise and renew-rather than merely revere-Shakespeare's art; and (3) that, in the last analysis, the translator is a kind of surrogate author (Hall 393). In desacralised translation, Shakespeare's poetry can be seen as useful foreign material, not sacred writ. And

${ }^{13}$ For an in depth problematisation of concepts such as "essence" and "authenticity" see James Clifford, especially 1-17 (see bibliography below). 
just as the cross-cultural encounters in Shakespeare's drama often show that "English culture could not understand itself except in juxtaposition to others" (Sousa 8), Shakespeare's originals can be illuminated and reforged, can be made intercultural and relevant, by means of cultural translation and desacralisation.

\section{References}

Aaltonen, Sirkku. Time-Sharing on Stage: Drama Translation in Theatre and Society. Topics in Translation 17. Clevedon: Multilingual Matters Ltd., 2000.

Barton, John. "Translation in the Theatre II: Translation as Adaptation". Interview with Mark Batty. In Translating Life: Studies in Transpositional Aesthetics. Eds. Shirley Chew and Alistair Stead. Liverpool: Liverpool UP (1999): 397-411.

Bassnett, Susan. "Ways through the Labyrinth: Strategies and Methods for Translating Theatre Texts". The Manipulation of Literature. Ed. Theo Hermans. New York: St. Martin's Press, 1985: 87-102.

Bloom, Harold. Como e Por Que Ler. Trans. José Roberto O'Shea. Rio de Janeiro:Editora Objetiva, 2001.

. Hamlet: Poem Unlimited. New York: Riverhead, 2003.

. Hamlet: Poema Ilimitado. Trans. José Roberto O'Shea. Rio de Janeiro: Editora Objetiva, 2004.

. How to Read and Why. New York: Scribner, 2000.

. Shakespeare: a Invenção do Humano. Trans. José Roberto O'Shea. Rio de Janeiro: Editora Objetiva, 2000. 
1998.

. Shakespeare: The Invention of the Human. New York: Penguin Putman,

Carbonell, Ovidio. “The Exotic Space of Cultural Translation”. Translation, Power, Subversion. Eds. Román Álvarez and M. Carmen-África Vidal. Topics in Translation 8. Clevedon: Multilingual Matters, Ltd. (1996): 79-98.

Clifford, James. The Predicament of Culture: Twentieth-Century Ethnography, Literature, and Art. Cambridge: Harvard UP, 1988.

Delabastita, Dirk. "Shakespeare in Translation: A Bird's Eye View of Problems and Perspectives". Accents Now Known: Shakespeare's Drama in Translation. Ed. José Roberto O’Shea. Ilha do Desterro 36: 1 (1999): 15-27.

Déprats, Jean-Michel. “'The 'Shakespearean Gap' in French.” Shakespeare Survey 50 (1997): 125-33.

Hall, Peter. "Translation in the Theatre I: Directing as Translating". Interview with Mark Batty. In Translating Life: Studies in Transpositional Aesthetics. Eds. Shirley Chew and Alistair Stead. Liverpool: Liverpool UP (1999): 387-96.

Hervey, Sándor \& Ian Higgins. Thinking Translation: A Course in Translation Method, French to English. London: Routledge, 1992.

Holderness, Graham, Ed. The Shakespeare Myth. Manchester: Manchester UP, 1988.

Johnston, David, ed. Stages of Translation. Bristol: The Longdunn P, 1996.

Kennedy, Dennis. Looking at Shakespeare: A Visual History of Twentieth-Century Performance. Second Edition. Cambridge: Cambridge UP, 2001.

. "Shakespeare without His Language". Shakespeare, Theory, and Performance. Ed. James C. Bulman. London and New York: Routledge (1996): 133-48.

Kennedy, Dennis, ed. Foreign Shakespeare: Contemporary Performance. Cambridge: Cambridge UP, 1993. 
Lings, Martin. Shakespeare in the Light of Sacred Art. London: Allen and Unwin, 1966.

Nida, Eugene. "Translating a Text with a Long and Sensitive Tradition". Translating Sensitive Texts: Linguistic Aspects. Ed. Karl Simms. Amsterdam: Rodopi (1997): 189-96.

O'Shea, José Roberto. Antônio e Cleópatra: A Report on a Translation in Progress". In Anais do VII Encontro Nacional da ANPOLL. Área de Letras - v.1. Associação Nacional de Pós-Graduação em Letras e Lingüística. Goiânia (1993): $364-71$.

Pavis, Patrice. Theatre at the Crossroads of Culture. Trans. Lauren Kruger. London: Routledge, 1992.

Simms, Karl. "Introduction”. Translating Sensitive Texts: Linguistic Aspects. Ed. Karl Simms. Amsterdam: Rodopi (1997): 1-26.

Sousa, Geraldo U. Shakespeare's Cross-Cultural Encounters. London: Macmillan, 1999.

Venuti, Lawrence. The Translator's Invisibility. London and New York: Routledge, 1995.

Recebido em: 17/01/2016

Aceito em: 15/04/2016 Publicado em setembro de 2016 